
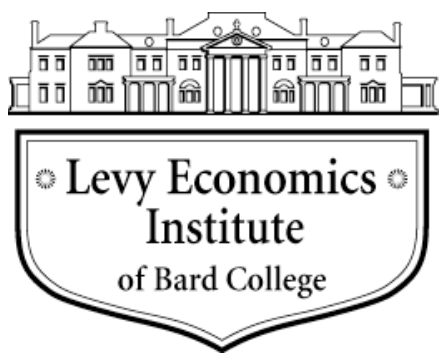

Working Paper No. 844

\title{
A Nonbehavioral Theory of Saving
}

by

\author{
Michalis Nikiforos* \\ Levy Economics Institute of Bard College
}

July 2015

\begin{abstract}
* Contact: mnikifor@levy.org. The author is grateful to Leilla Davis, Mark Setterfield, and Willi Semmler, as well as the participants of the 41st Eastern Economic Association Annual Conference in New York and the macroeconomic theory workshop at The New School for Social Research, for their useful comments and suggestions. The author also thanks Steven Fazzari and Barry Cynamon for generously providing the time series of the household sector saving rates. The usual disclaimer applies.
\end{abstract}

The Levy Economics Institute Working Paper Collection presents research in progress by Levy Institute scholars and conference participants. The purpose of the series is to disseminate ideas to and elicit comments from academics and professionals.

Levy Economics Institute of Bard College, founded in 1986, is a nonprofit, nonpartisan, independently funded research organization devoted to public service. Through scholarship and economic research it generates viable, effective public policy responses to important economic problems that profoundly affect the quality of life in the United States and abroad.

Levy Economics Institute

P.O. Box 5000

Annandale-on-Hudson, NY 12504-5000

http://www.levyinstitute.org

Copyright (C Levy Economics Institute 2015 All rights reserved

ISSN 1547-366X 


\begin{abstract}
We present a model where the saving rate of the household sector, especially households at the bottom of the income distribution, becomes the endogenous variable that adjusts in order for full employment to be maintained over time. An increase in income inequality and the current account deficit and a consolidation of the government budget lead to a decrease in the saving rate of the household sector. Such a process is unsustainable because it leads to an increase in the household debt-to-income ratio, and maintaining it depends on some sort of asset bubble. This framework allows us to better understand the factors that led to the Great Recession and the dilemma of a repeat of this kind of unsustainable process or secular stagnation. Sustainable growth requires a decrease in income inequality, an improvement in the external position, and a relaxation of the fiscal stance of the government.
\end{abstract}

Keywords: Inequality; Financial Balances; Saving; Secular Stagnation; Sustainability JEL Classifications: E12, E21, E32, E60 


\section{INTRODUCTION}

One of the most interesting concepts in macroeconomic analysis is what Taylor and Lysy (1979) baptized as "closure": the direction of causality among the macroeconomic variables. Different economic models (often from different schools of thought) assume a different direction of causality, a different set of exogenous and endogenous variables.

The concept of closure goes back at least to the Alternative Theories of Distribution of Nicholas Kaldor (1955). Kaldor explains how the macroeconomic models of the various economic traditions specify different paths of causality among the macroeconomic variables and come up with alternative theories of distribution (and growth). ${ }^{1}$

Of particular interest is what Kaldor calls "the Keynesian theory" of distribution. Kaldor examines a closed economy without a government sector. The economy is divided in two classes: workers and capitalists, whose income is wages $(W)$ and profits $(\Pi)$. Their saving rates $\left(s_{w}\right.$ and $s_{\pi}$, respectively) are assumed to be exogenous. Kaldor also assumes an exogenous level of investment $I$, that guarantees full employment. Under these assumptions, the basic macroeconomic identity that investment is equal to total saving $(I=S)$ is satisfied through the endogenous determination of distribution. In other words, since investment and the saving rates are exogenous, the only way for the identity $I=S=s_{w}+\left(s_{\pi}-s_{w}\right) \Pi$ to be satisfied is through the endogenous adjustment of distribution. If we divide both sides of this equation with output $(Y)$ and rearrange, it is easy to see that the profit share becomes a function of the saving rates and the share of investment in demand $(I / Y)$, while if we divide with the capital stock, the profit rate $(I / K)$ becomes a function of the rate of growth of capital stock $(g=I / K)$. Thus, this Kaldorian "Keynesian" theory of distribution specifies a direction of causality that runs from investment and the saving rates toward distribution. ${ }^{2}$

In order to understand Kaldor's motivation when he proposed this theory of distribution, we need to keep in mind that it is very much driven by his empirical observations. Kaldor sets out to explain his most famous "stylized fact" (Kaldor, 1957), the constancy of the functional distribution of income. Moreover, it is clear all along that in his analysis Kaldor had in mind, what he calls, the "successful capitalist economies of Western Europe and North America" which in the mid-1950s seemed to have achieved a robust "balanced" growth and full employment. For such economies, he argues, we can assume that investment and the growth rate are determined by the exogenous growth of population and productivity — so as to guarantee full employment - and are thus exogenous themselves. The capital-output ratio $(v)$ is also considered to be constant—another one of his stylized facts. As a result the economy follows a balanced growth path with full employment.

\footnotetext{
${ }^{1}$ Except for Kaldor an early exploration of the concept of closure (without calling it that way) is provided by Sen (1963). More complete treatments can be found in Marglin (1984), Foley and Michl (1999) and Taylor (2004).

${ }^{2}$ Because of the assumption of full employment Sen (1963) calls this theory "Neo-Keynesian" as opposed to the original Keynesian theory where employment is endogenous.
} 
The observation-driven nature of Kaldor's theory is important because he dismisses the classical theory of distribution - in its Ricardian and Marxian form - on this basis; because it does not explain the observed constancy of the share of wages and profits in total income. For example, in the introduction of the article, he writes:

The famous "historical constancy" of the share of wages in the national income-and the similarity of these shares in different capitalist economies, such as the U.S. and the U.K.- - was of course an unsuspected feature of capitalism in Ricardo's day. But to the extent that recent empirical research tends to contradict Ricardo's assumption about the variability of relative shares, it makes the question of what determines these shares, more, rather than less, intriguing. In fact no hypothesis as regards the forces determining distributive shares could be intellectually satisfying unless it succeeds in accounting for the relative stability of these shares in the advanced capitalist economies over the last 100 years or so...(emphasis added, p. 83-84).

It is also important to keep in mind that despite the assumption of full employment the principle of effective demand holds (hence the name Keynesian) because investment is determined autonomously and does not just (inexplicably) follows saving. Quite the opposite; as we explained above, it is saving - through changes in distribution - that adjusts to the investment decisions. The difference with the more conventional Keynesian theory is that the multiplier principle is applied in reverse. Investment (through the multiplier) determines distribution, as opposed to output and employment.

As it is well known, the theory of Kaldor was further elaborated by Pasinetti (1962). Pasinetti proved the famous theorem (that was named after him) that under the Kaldorian assumptions the distribution of income is determined only as a function of the growth rate and the saving propensity of the capitalists; the saving rate of the workers does not play any role. However, Pasinetti is more cautious than Kaldor in the interpretation of the results. In a passage in the concluding section of the article that usually passes unnoticed he writes:

Mr. Kadlor presented his theory of income distribution, he pointed out that the interpretative value of the theory depends on the Keynesian hypotheses on which it is built. In particular it depends on the crucial hypothesis (post-Keynesian rather than Keynesian) that investment can be treated as an independent variable governed by technical progress and population growth.

But this is not the approach that I should like to take here. Whether we are or whether we are not prepared to accept the model in this behavioural sense, there are important practical implications which are valid in any case. I should look, therefore, at the previous analysis simply and more generally as a logical framework to answer interesting questions 
about what ought to happen if full employment is to be kept over time, more than as a behavioural theory expressing what actually happens (p. 279 emphasis added).

From this passage, it becomes clear that, unlike Kaldor, Pasinetti did not view his model as an actual "behavioral" theory of distribution but rather as an analytical tool -a "logical framework"- that allows us to specify the necessary conditions for the maintenance of full employment.

Half a century later, the Kaldorian theory of distribution does not seem convincing for the simple reason that the experience of the last three decades has disproved the "famous historical constancy" of the income shares. In the US, the UK, and most of the other developed economies there has been a significant decrease in the share of wages. The redistribution of income in favor of capitalists becomes even more pronounced if we examine the size distribution of income and analyze the trajectories of the share of income of the top $1 \%$ or $10 \%$ against the rest. These developments can only be reasonably explained by the continuous change in the balance of power against the working class and other institutional factors and are thus more in line with the classical theory of distribution. ${ }^{3}$

Nevertheless, the logical framework of Kaldor and Pasinetti remains useful. We can still "answer interesting questions about what ought to happen if full employment is to be kept over time" when output and employment are determined from the demand side, as Keynes suggested, and in the face of an institutionally determined - exogenous - distribution of income, as proposed by the classical political economists.

In this case, since both distribution and growth are exogenous, another variable has to bear the burden of adjustment. The only candidate - in a closed economy with no government—is the saving rate, or the saving propensities of the two classes. Such a model can provide a theory of saving, as opposed to a theory of distribution. As Pasinetti emphasized, we do not need to accept this theory in a behavioral sense but rather as a logical framework that will allow us to examine how saving is determined for certain levels of the distribution of income if full employment is to be kept over time. We will call it a non-behavioral theory of saving.

Our analysis can also be extended to include the government and the foreign sector. In that case, the degrees of freedom of the model increase, and closure becomes more flexible. The maintenance of full employment can also be accommodated by the government or the foreign sector. In an open economy with a government sector, specifying a theory of saving for the (domestic) private sector, or a subsector of the private sector, requires us to further assume that the government and foreign saving are exogenous. This is the line of the argument of the Seven Unsustainable Processes by Godley (1999). Godley tries to sketch "what ought to happen if full employment is to be kept over time" in the face of an exogenous increase in the current account deficit and (an also exogenous) fiscal consolidation. His

\footnotetext{
${ }^{3}$ Recent contributions along "Kaldorian" lines (e.g. Ryoo, 2015) explain the changes of the last three decades in the distribution of income as the result of the exogenous changes in the long-run growth rate and the saving rate. As we explain this kind of explanation is not consistent with Kaldor's justification of his theory of distribution.
} 
answer is an implicit non-behavioral theory of saving for the private sector: the private sector needs to save less and run large deficits. From this point of view, Godley's argument is, in a way, Kaldorian. ${ }^{4}$

Godley's analysis omitted distributional issues. His implicit non-behavioral saving theory is limited to the private sector as a whole, or in some cases, to firms and households. In the present article we go one step further and decompose the household sector into distributional classes. Unlike Kaldor and Pasinetti we do not use the functional but the size distribution of income, and we split the household sector into the bottom $90 \%$ and the upper 10\%. The advantage of this approach is that it allows us to explicitly examine the redistributive role of the government, as well as the distribution of the wage bill between the households at the top and the bottom of the distribution. We derive a non-behavioral theory of saving for the bottom $90 \%$ of the distribution. In the face of an in increase in income inequality - or an increase in the current account deficit or the fiscal balance - and if the saving rate of the top $10 \%$ remains constant, full employment hinges on the decrease in the saving rate of the bottom $90 \%$.

An interesting corollary of a theory of saving is that it allows us to draw conclusions about the trajectory of the debt and net worth - and their ratios to income - of the sectors under examination. A negative saving rate will tend to increase the debt and decrease the net worth of a sector (and the respective ratios to income). As Hyman Minsky $(1975,1986)$ emphasized, such a process, that entails a continuous deterioration of the balance sheets - the transition from a hedge, to a speculative and then a Ponzi position - is not sustainable and is bound to collapse sooner or later.

These linkages between distribution, demand, growth, saving and then debt and net worth are crucial in order to understand the processes that led to the Great Recession and stand in the way of a sustainable recovery. The decades before the crisis were marked by increasing income inequality, external deficits and fiscal conservatism. Thus, full employment could only be maintained through a very large decrease in the saving rate of the households, especially those at the bottom of the distribution, and an increase in their debt-to-income ratio. It was possible to maintain this process for such an extended period of time because of the asset bubbles that marked this period, first the stock market bubble of the 1990s and then the real estate bubble of the 2000s. The crisis came as the natural outcome of these processes when the saving rate of the households stopped decreasing and the bubbles burst.

This approach to the crisis is also important for understanding the present of future challenges of economic policy. Given the present levels of inequality, the high external deficits and the pervasive fiscal conservatism (the current recovery is the only one in the post-war history of the US that the government expenditure has decreased in real terms) a recovery can come only through another round of unsustainable increase in spending of households, especially those at the bottom of the distribution.

\footnotetext{
${ }^{4}$ Kaldor was one of the major influences of Godley's economics. Their paths crossed when they were both working for the Treasury and it was Kaldor who invited Godley to join the University of Cambridge. Godley famously said that Kaldor was touched by genius.
} 
The alternative is what we experience now, a prolonged period of low growth and employment, a secular stagnation. Under this prism, a sustainable recovery requires the decrease in income inequality and the foreign deficits and the relaxation of the fiscal stance of the government.

A final question is if a non-behavioral theory is useful or not. The answer is positive. To a certain extent the macroeconomic performance of an economy depends only on the behavior of the agents itself and is independent from the motives that lead to this behavior. In the context of a Keynesian model what matters is aggregate demand. To a large extent it does not matter if aggregate demand is generated by "rational" households who take first derivatives of Langrangian and Hamiltonian functions at the dinner table every evening or by "irrational" ("immoral") households on a spending spree. By saying this, we do not mean that the motives of the agents are not important or that it is not worth trying to understand them; quite the opposite. In fact, toward the end of the paper we show that our non-behavioral theory is consistent with behavioral explanations and a rich literature on the theory of consumer behavior that goes back to classical political economy, Thorstein Veblen (1899) and James Duesenberry (1949).

The paper proceeds as follows. In the next section we set the stage with a necessary brief discussion of the accounting relationship between saving, debt and net worth. Section 3 discusses the Seven Unsustainable Processes and how in the face of high current account deficits and fiscal consolidation full employment becomes dependent on low saving rates on behalf of the private sector-especially households. In section 4 we discuss income inequality and show that an increase in

inequality necessitates the decrease of the saving rate of the households at the bottom of the distribution for full employment to be maintained. Sections 5 and 6 relate our discussion with ongoing debates about the roots of the crisis and the idea of secular stagnation. In section 7 we provide a brief overview of possible behavioral foundations of our "non-behavioral" theory. Section 8 concludes.

\section{SAVING, DEBT AND NET-WORTH}

Before moving to the main body of the paper, some simple accounting exercises on the relation between saving debt and net worth will help us develop our argument in the subsequent sections. A basic accounting principle that holds for any economic agent or sector of the economy, say $i$, is that its net worth $\left(\Omega_{i}\right)$ is the difference between the value of its assets and its liabilities. If we assume that there is only one class of assets $(A)$ with price $P_{A}$, and debt $(D)$ is the only liability, the net worth of $i$ is $\Omega_{i}=P_{A} A_{i}-D_{i}$ and the change of the net worth is equal to saving plus capital gains: $\dot{\Omega}_{i}=S_{h}+\dot{P}_{A} A_{i}$. If the real disposable income of $i$ is $Y_{i}^{d}$ and the general price level is $P$ we can write the equations of motion of the net-worth-to-income and debt-to-income as

$$
\left[\frac{\dot{\Omega}_{i}}{P Y_{i}^{d}}\right]=s_{i}-\left(\pi+g_{i}\right) \frac{\Omega_{i}}{P Y_{i}^{d}}+\pi_{A} \frac{P_{A} A_{i}}{P Y_{i}^{d}}
$$




$$
\left[\frac{\dot{D}_{i}}{P Y_{i}^{d}}\right]=-s_{i}-\left(\pi+g_{i}\right) \frac{D_{i}}{P Y_{i}^{d}}+\hat{A}_{i} \frac{P_{A} A_{i}}{P Y_{i}^{d}}
$$

where, $s_{i}$ is the saving rate of $i$ (the ratio of total saving to disposable income, $S_{i} / P Y_{i}^{d}$ ), $g_{i}$ is the growth rate of its real disposable income, $\pi$ and $\pi_{A}$ are the inflation rate and the asset price inflation rate, and $\hat{A}_{i}$ is the growth rate of the holdings of assets.

From equations (1) and (2)we can see that, ceteris paribus, a decrease in the saving rate will decrease the net-worth-to-income ratio and increase the debt-to-income ratio. An increase in the rate of inflation or the growth rate will tend to decrease both ratios, since it will increase the denominator of the related fraction. Finally, asset inflation (weighted by the ratio of the value of assets to nominal income) increases the net-worth-to-income ratio, while purchases of new assets (again weighted by the ratio of the value of assets to nominal income) will increase the debt-to-income ratio.

Another important factor for the trajectory of the debt- and net-worth-to-income ratios is the interest rate on debt. In equations (1) and (2) the role of interest is hidden with the saving rate. If we denote the interest rate as $\iota$ we can split the total saving to the "primary saving" and interest payments: $S_{i}=S_{i}^{p}-\iota D$ which can be rewritten as $s_{i}=s_{i}^{p}-\iota\left(D / P Y^{d}\right)$. In this case $s_{i}^{p}$ is the "primary saving rate." If we replace this definition of the overall saving rate into (1) and (2), it is easy to see that the interest rate has a negative effect on $\Omega_{i} / P Y_{i}^{d}$ but a positive one on $D / P Y_{i}^{d}$.

From the above discussion it becomes obvious that a negative saving rate-especially if it persists for an extended period of time - will lead to the explosion of the debt-to-income ratio and the shrinkage of the net worth. ${ }^{5}$ Such a process is unsustainable and is bound to collapse.

\section{THE SEVEN UNSUSTAINABLE PROCESSES}

Godley's Seven Unsustainable Processes (1999) is a seminal piece on economic policy. It is distinguished by the clarity of the exposition of its argument and also the accuracy of its predictions. What makes it even more impressive is that it was written at a time when the vast majority of economists and policymakers held a diametrically opposed view on the prospects of the US and the global economy. The year 1999 was the peak of the optimism about the capabilities of the "new economy" to generate and sustain growth and wealth. The US economy had been expanding for nearly eight years, the budget was in surplus, and inflation and unemployment had both fallen substantially. The Council of Economic Advisers was forecasting that GDP would grow by 2.5\% between then (1999) and the year 2005 and the $\mathrm{CBO}$ was projecting a rise in the budget surplus through the next 10 years. ${ }^{6}$

\footnotetext{
${ }_{5}^{5}$ Obviously the other elements of equations (1) and (2) are also important. For example, Mason and Jayadev (2014) emphasize the importance of the role of the interest rates, the growth rate of income and the rate of inflation for the path of the debt-to-income ratio of the US households.

${ }^{6}$ As Godley mentions in the the report, Alan Blinder compared the United States economy to one of its mighty rivers - it would "just keep rolling along," while president Bill Clinton in the economic report of the president of that year was
} 
Godley was not that impressed. He wrote that the important question to ask is "whether the present stance of ... policy is structurally appropriate looking to the medium- and long-term future" (p. 3). After the examination of the sources of the growth of the US economy, he identified seven unsustainable processes.

Figure 1: US main sector balances 1960-2014 (\% of GDP)

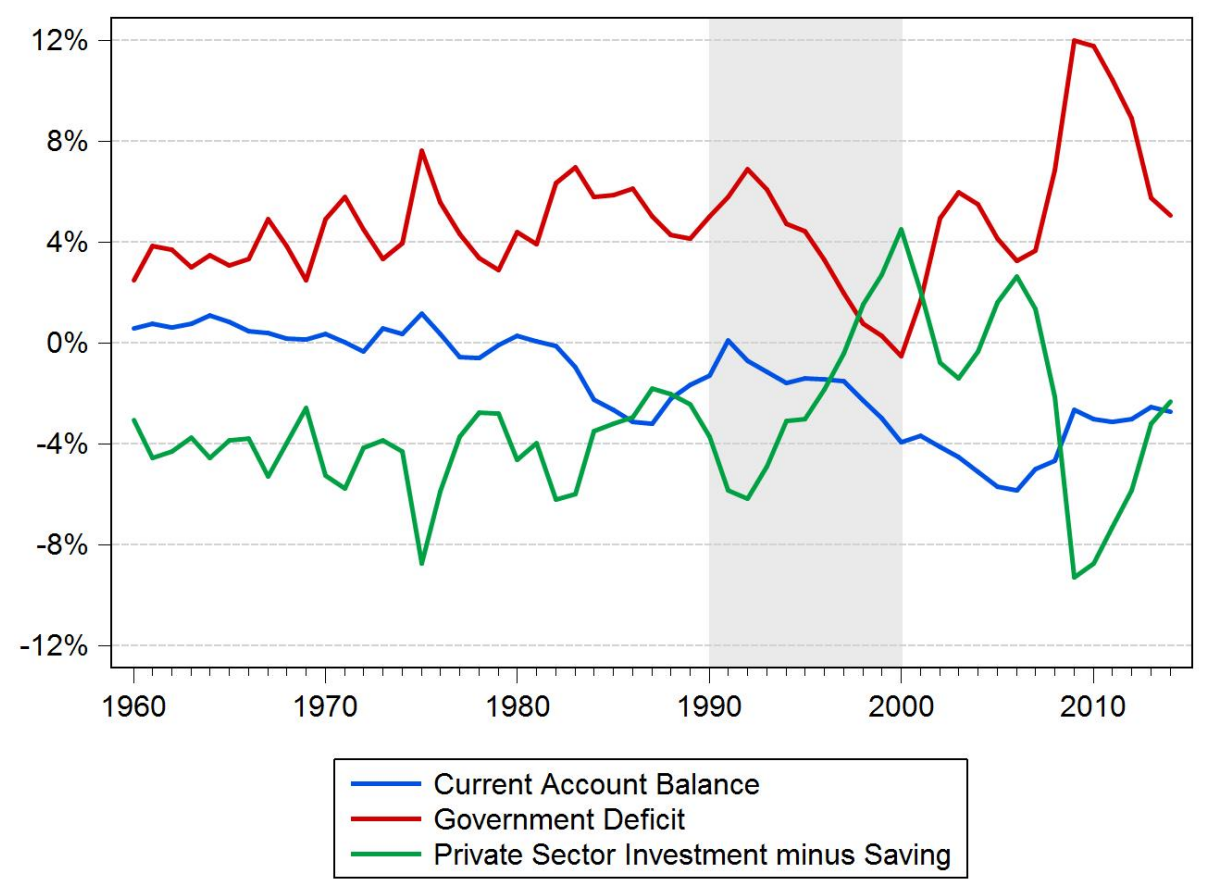

Sources: BEA, author's calculations

To understand the argument by Godley we need to examine the financial balances of the three institutional sectors of the US economy, presented in Figure 1. The pattern that prevailed until the 1980s was a balanced current account and a government deficit that was mirrored with a surplus of the private sector. This situation changes in the 1990s (the shaded area of the figure). This period is marked by rapid deterioration of the current account balance. According to Godley this was due to the "successful invasion of U.S. markets by foreign manufacturers and increased outsourcing of intermediate products" (p. 6). At the same time government consolidated its budget and achieved a fiscal surplus by the end of the decade. By accounting principle this was matched by a spectacular increase in the net borrowing of the private sector. After running surpluses around $5 \%$ for the whole post-WWII period the private sector switched gears and reached a deficit of 5\% by the end of the decade - a difference of $10 \%$ of GDP!

In the light of Figure 1 Godley's argument is simple. If an economy faces "sluggish net export

writing that "there are no limits to the world we can create, together, in the century to come." 
demand" (due to the successful invasion of its markets by foreign competitors) and fiscal policy is restrictive, economic growth becomes "dependent on rising private borrowing"—on the private sector's continuing to spend in excess of its income.

Notice, the logical framework of the argument and the implied closure. In essence Godley is saying that if full employment is to be kept over time, and given the rising external deficit and fiscal conservatism of the time (an exogenous decrease in trade surplus and fiscal deficit), the - endogenousvariable that needs to bear the burden of adjustment is the saving of the private sector; the saving rate has to become negative. This is what we have called a non-behavioral theory of saving.

However, Godley continues, a continuous negative saving rate leads to the accumulation of private debt and increase in the private sector debt-to-income ratio. Thus, this process is not sustainable in the medium and long run. Finally, Godley argues that because growth is so dependent on "rising private borrowing," the real economy "is at the mercy of the stock market to an unusual extent. A crash would probably have a much larger effect on output and employment now than in the past" (p.3). Before the rooster crowed, the analysis of Godley's analysis was validated by the crisis of 2001 and a few years later by the Great Recession of 2007-09.

More formally, Godley's argument can be understood with the help of the Social Accounting Matrix (SAM) of Table 1. Unlike the economy of Kaldor and Pasinetti, the economy is open, there is a government sector, the household sector is treated as a whole, but there is a distinction between households and firms. $P^{*}$ and $e$ stand for the price level abroad and the exchange rate. By construction of the matrix, the sum of each row is equal to the sum of its respective column. The first row summarizes the decomposition of output from the expenditure side: output $(P Y)$ is equal to the sum of household consumption $(P C)$, government expenditure $(P G)$, exports minus imports $\left(P X-e P^{*} M\right)$ plus investment $(P I)$. From the side of the cost, output is decomposed in the first column into wages $(W)$ and profits (П); wages are directly distributed to households, while profits are earned by the firms. Rows (B) to (E) and columns (2) to (5) show the transfers between the sectors of the economy. The first letter of the subscript stands for the source of the transfer, while the second letter for the receiver. The total income of each sector is equal to its primary income (if any) plus the transfers it receives from other sectors. For example, the total income of the household sector $\left(Y_{h}\right)$ is equal to wages plus the transfer of income from the firms (the distributed profits $Q_{c h}$ ) plus the transfers from the government and the rest of the world ( $Q_{g h}$ and $Q_{f h}$ respectively). On the other hand, the total expenditure of each sector is equal to its primary expenditure in the first row of the SAM plus the transfers it make to other sectors. For example, the total outlays of the households sector is equal to consumption plus the transfers it makes to the government (essentially the taxes $T=Q_{h g}$ ) and the transfers to the foreign sector $\left(Q_{h f}\right)$.

The discrepancy between the income and the outlays of each sector is equal to its saving, which can be seen in the flow of funds row of the SAM. This row of the SAM also shows the basic accounting identity, which we already discussed in the introduction, that total saving is equal to investment: 


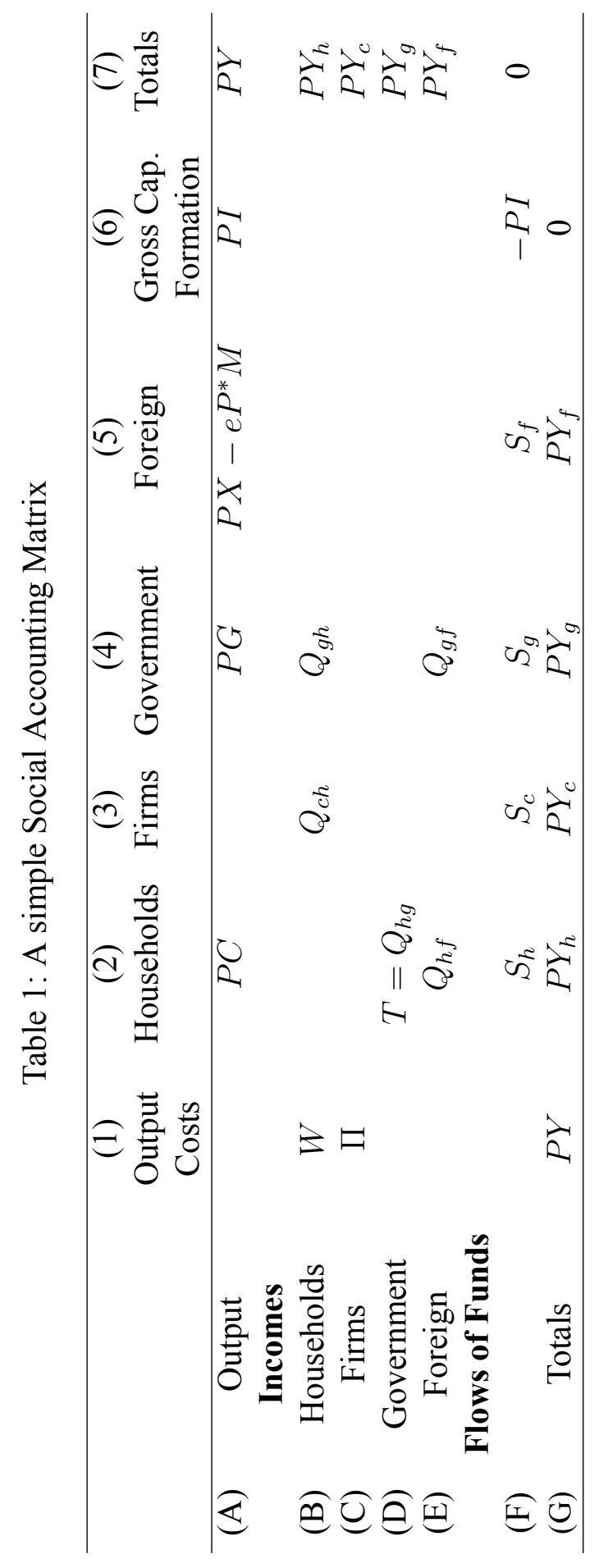




$$
S=S_{h}+S_{c}+S_{g}+S_{f}=P I
$$

Compared to the economy of Kaldor and Pasinetti, the different sectoral composition of the economy provides respectively different sources for saving.

With some trivial algebra based on the accounting identities of the SAM, this equation can be rewritten as

$$
\left\{S_{p}-P I\right\}=\left\{(P G-T)+\left(Q_{g h}+Q_{g f}\right)\right\}+\left\{\left(P X-e P^{*} M\right)-\left(Q_{h f}+Q_{g f}\right)\right\}
$$

where $S_{p}=S_{h}+S_{c}$ is the total saving of the private sector. Equation (4) presents the financial balances of the three institutional sectors of the economy; It is obvious that these "three balances" are just another representation of the basic macroeconomic identity that saving is equal to investment. On the left-hand side (LHS) of the equation there is the surplus of the private sector. The first term on the right-hand side (RHS) of the equation is the government deficit. The second term is the current account balance, which is decomposed into the net exports $\left(P X-e P^{*} M\right)$ and the net income transfers $\left(Q_{f h}-Q_{h f}-Q_{g f}\right)$. Thus, the surplus of the private sector is equal to the sum of the government deficit and current account surplus.

If then we denote total private saving, government deficit and current account surplus as a ratio to total income as $\sigma_{p}, d$ and $c a$ respectively, the above equation can be rewritten as

$$
\sigma_{p}-g v=d+c a
$$

This is the form in which the balances were presented in Figure 1.

Now we can go back to Kaldor (1955), Pasinetti (1962), Godley (1999) and our non-behavioral theory of saving. Assume that the capital output ratio $(v)$ is exogenous like in Kaldor and Pasinetti. In the face of a "successful invasion" of domestic markets from foreign exporters, and if fiscal policy becomes restrictive - if $c a$ and $d$ decrease - the only way for the economy to maintain full employment (a constant $g$ at the full employment level) is through a decrease in the saving of the private sector's saving relative to income. In other words, if $c a$ and $d$ on the RHS of equation (5) decrease, the only way for $g$ to remain constant is for $\sigma_{p}$ to decrease by the same amount. If we rearrange, we get a first expression for the required saving of the private sector over total income:

$$
\sigma_{p}=g v+d+c a
$$

If we further define $s_{p}$ as the saving rate of the private sector, the ratio of private saving over total private disposable income, $S_{p}=s_{p} P Y_{p}^{d}$, and $\rho$ as the share of private income over total income 
$P Y_{p}^{d}=\rho P Y$, we can rewrite (5) as

$$
s_{p}=(g v+d+c a) / \rho
$$

In this case, the role of the multiplier is played by the ratio of total income over private disposable income, $1 / \rho$.

Going one step further, the total saving rate can be decomposed into a weighted average of the saving rate of the household and the corporate sector:

$$
s_{p}=s_{h} \cdot \frac{Y_{h}^{d}}{Y_{p}^{d}}+s_{c} \cdot \frac{Y_{c}^{d}}{Y_{p}^{d}}
$$

The saving rate of the corporate sector is usually positive. Therefore, the saving rate of the household sector has to be even smaller than overall private sector saving rate as a whole.

More generally, if we combine equations (7) and (8) we end up with the following relation for the saving rate of the household sector

$$
s_{h}=\frac{(g v+d+c a)}{\rho_{h}}-s_{c} \cdot \frac{\rho_{c}}{\rho_{h}}
$$

where $\rho_{h}$ and $\rho_{c}$ are the shares of the household and corporate income in total income. Equation (9) is giving us the saving rate of the household sector necessary for full employment to be maintained, for different combinations of the current account balance, the government deficit as well as the retained earning ratio of the firms.

As we explained in the previous section knowing the saving rate of a sector allows us to trace the trajectory of its balance sheet. If we plug quation (9) into equations (1) and (2) we get

$$
\begin{aligned}
& {\left[\frac{\dot{\Omega}}{P Y_{h}^{d}}\right]=\left\{\frac{(g v+d+c a)}{\rho_{h}}-s_{c} \cdot \frac{\rho_{c}}{\rho_{h}}\right\}-\left(\pi+g_{h}\right) \frac{\Omega}{P Y_{h}^{d}}+\pi_{A} \frac{P_{A} A}{P Y_{h}^{d}}} \\
& {\left[\frac{\dot{D}}{P Y_{h}^{d}}\right]=-\left\{\frac{(g v+d+c a)}{\rho_{h}}-s_{c} \cdot \frac{\rho_{c}}{\rho_{h}}\right\}-\left(\pi+g_{h}\right) \frac{D}{P Y_{h}^{d}}+\hat{A} \frac{P_{A} A}{P Y_{h}^{d}}}
\end{aligned}
$$

The non-behavioral theory of saving of the household sector implicitly gives us the link between the balance sheets of the household sector with the full employment growth rate and the fiscal and current account balances.

Equations (1') and (2') show that the balance sheets of the household sector is the final destination of the increase in the current account deficit and fiscal consolidation in an economy; an increase in the current account deficit or the fiscal surplus will tend to decrease the net-worth-to-income ratio and increase the deb-to-income ratio if full employment is to be maintained.

The above equations also show that the balance sheets of the private sector and the house- 
holds are linked to the fiscal stance and thus the balance sheets of the government. The effort of the government to consolidate its budget makes full employment dependent on other sources of demand. If at the same time foreign demand is weak, the burden of adjustment falls on the private sector and the households. Therefore, the desirable improvement in the balance sheets of the government might lead to increasingly fragile balance sheets of the private sector. Many times this point is ignored in the debates on economic policy and employment in the United States and Europe.

Finally, equations ( $\left.1^{\prime}\right)$ and (2') reveal one of the aspects of Godley's argument that the real economy "is at the mercy of the stock market to an unusual extent." When the saving rate of the household sector is positive, the tendency for a decrease of its net worth is counteracted by asset price inflation. An asset price bubble can hide the unsustainability of this process by inflating the asset side of the balance sheets of the households. In this way, households can continue borrowing for more time than they would be able without asset price inflation. Alternatively, if households cash in their capital gains - a negative $\hat{A}$ in equation (2') - the increase in the debt-to-income ratio would be smaller.

\section{INCOME INEQUALITY: THE 8TH UNSUSTAINABLE PROCESS}

Godley largely ignored distribution of income in his theoretical and policy work. However, a careful examination of the increasing income inequality is necessary to understand the roots of the crisis of 2007-2009 and the feeble recovery that has followed.

Figure 2: Top 10\% Income Share, 1917-2012 (\% of total income)

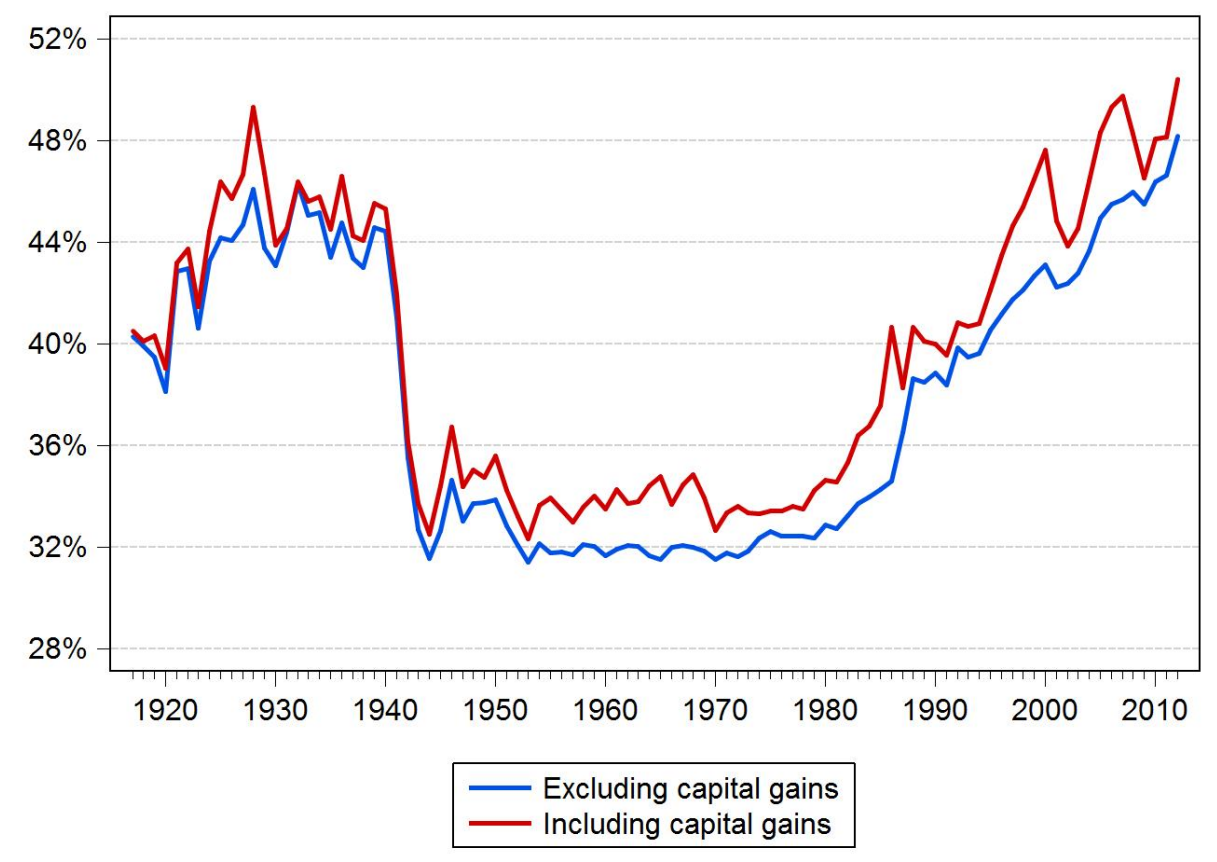

Source: Alvaredo et al. (2014) 
Figure 2 presents data from The World Top Incomes Database (Alvaredo et al., 2014) on the income share of the Top 10\% of the population in the United States for the period 1917-2012. As we can see, beginning in the early 1980s the income share of the Top 10\% started increasing. On the eve of the crisis of 2007, it reached the levels it had reached before the crisis of 1929; a difference of the present situation compared to the 1930s is the income share of the richest part of the population bounced back and has continued to increase after the crisis.

This increase in the income share at the top meant that the income of the rest of the population stagnated. Figure 3 shows that the real average income of the bottom $90 \%$ of the population doubled in the first three decades after the war but has stagnated since. In fact, the real average income of the bottom $90 \%$ in 2012 was lower than it was forty years before.

Figure 3: Index of Personal Consumption Expenditure per Capita and Average Income of the Bottom 90 Percent, 1945-2012 (1945=100)

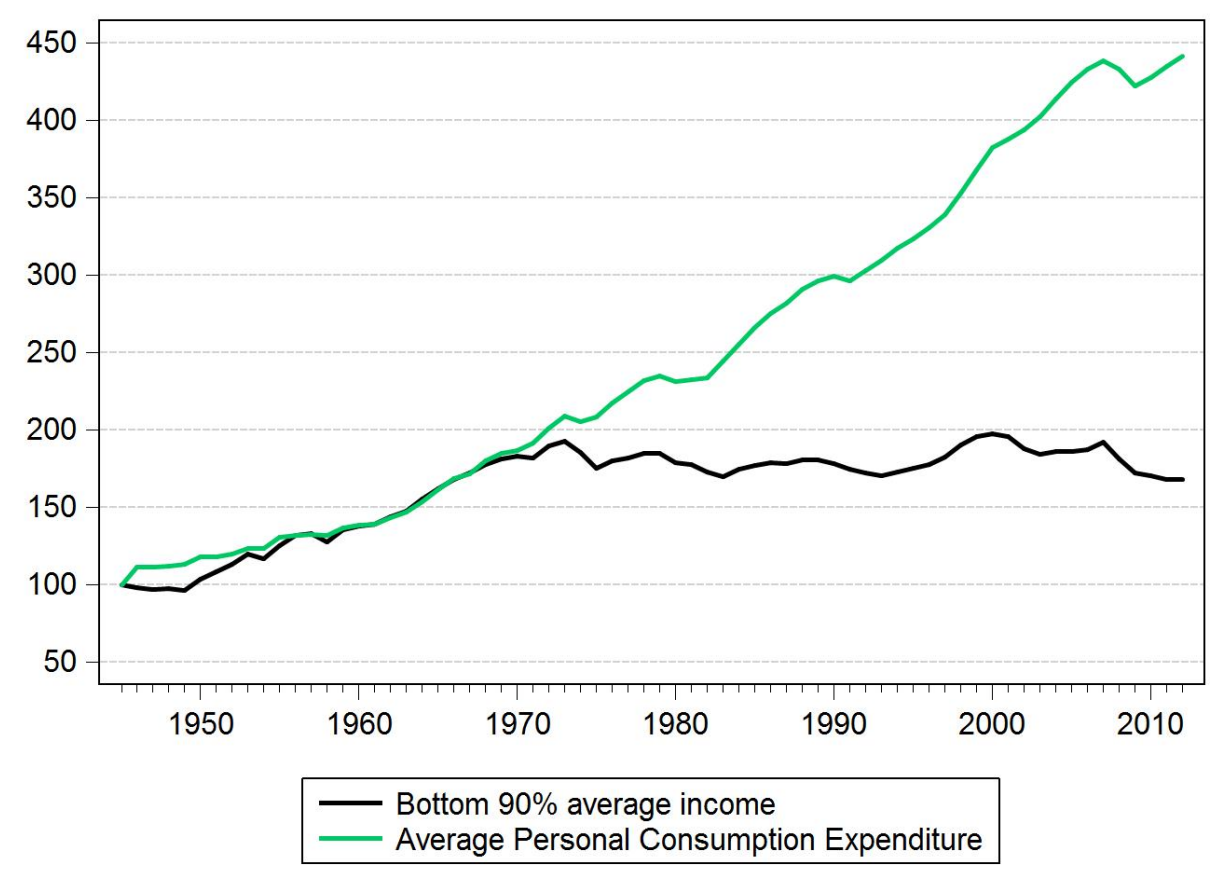

Sources: BEA, Alvaredo et al. (2014), US census, author's calculations

In the same graph we present an index for the real average personal consumption expenditure. Due to lack of the data the index refers to the whole population and not only to the bottom $90 \%$. There are two interesting observations we can make about average consumption. First, its behavior has not really changed over the whole post-war period and (at least before the recent crisis) it increased at roughly the same rate. Second, in the first three decades after the war, average consumption was increasing at the same pace with the average income of the bottom $90 \%$. In the last four decades, as the income of the bottom $90 \%$ stagnated an increasingly large gap between the two has been created. 
To the extent that this gap was not filled by the consumption of the top $10 \%$, it had to be filled by increasing borrowing from the households at the bottom of the distribution. ${ }^{7}$

Figure 4: Household Sector Saving Rate

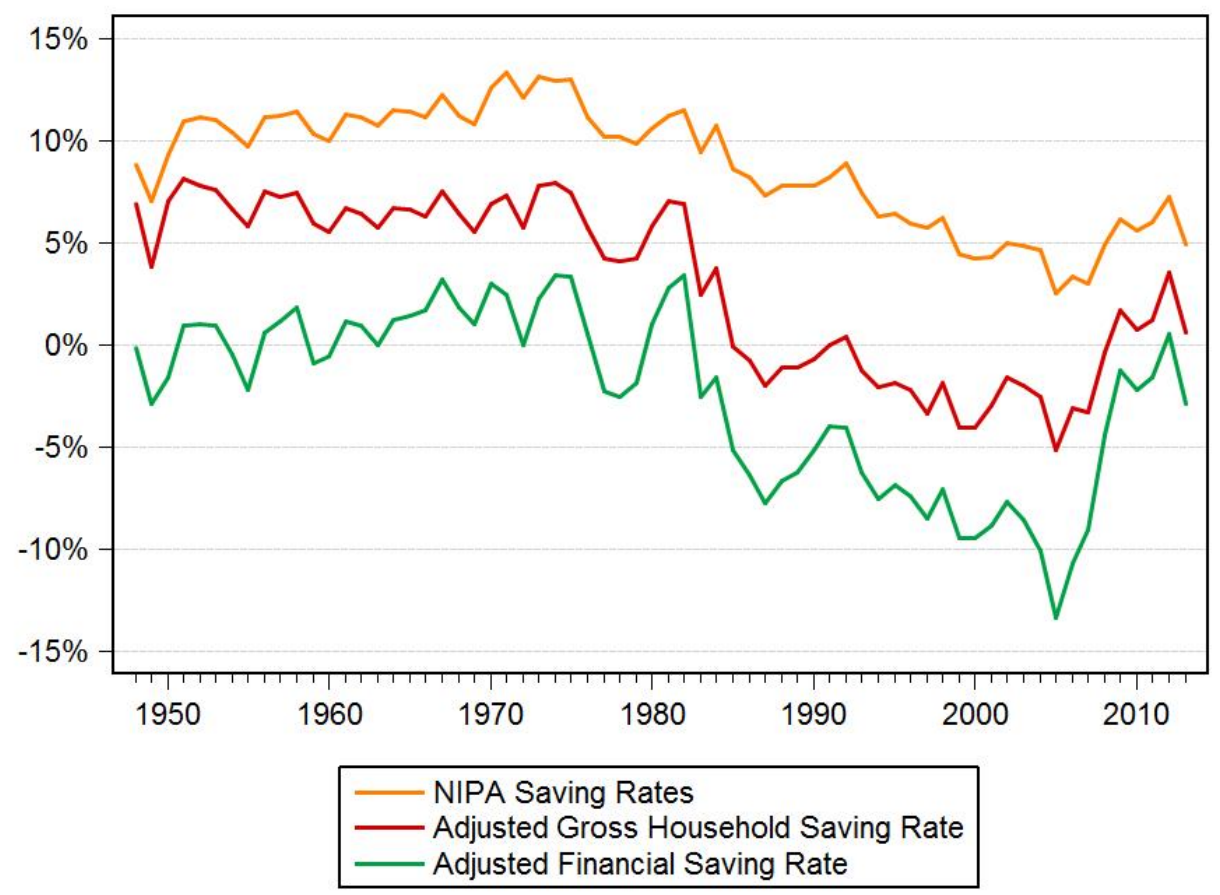

Sources: BEA, Cynamon and Fazzari (2015a), author's calculations

The divergent paths of consumption and the income of the bottom $90 \%$ are reflected in the saving rate of the households. Figure 4 presents different measure of the households saving rate. All three different measures show a constant saving rate until the mid-1970s, the period when the average income of the bottom $90 \%$ and the average consumption moved together. This is followed by a rapid decrease of this saving rate until the eve of the Great Recession - the period of the great divergence in figure 3. The upper line in figure 4 presents the saving rate of the personal sector from the NIPA accounts. The personal sector includes Households and Nonprofit Organizations. The saving rate is defined as simply the difference between (personal) consumption expenditure from disposable income over disposable income. As we can see, it decreased from $13 \%$ in 1975 to $2.5 \%$ in 2005 and $3 \%$ in 2007; a change of more than 10 percentage points.

In a recent paper Cynamon and Fazzari (2015a) construct alternative measures of saving for the household sector, which are more relevant for our discussion. They do it by making a series of adjustments to the disposable income and the expenditure of the household sector that "reflect the actual cash receipts and expenditures of households." The most important of these adjustments is to exclude

${ }^{7}$ A more detailed exposition of this argument is provided by Palma (2009, p. 842-843). 
the implicit rental income of homeowners from both the disposable income and the expenditure of the household sector. Another adjustment they make is to exclude the Nonprofit from the Household sector. With these and other adjustments that are explained in detail in their paper they arrive at the "Adjusted Gross Household Saving Rate." This measure shows a more pronounced drop of the saving rate, around $13 \%$, in the three decades before the crisis. More important, as opposed to the NIPA saving rate that is always positive, this measure of the saving rate became negative in the 1990s and reached $-5.2 \%$ in 2005 .

Another important adjustment they make is to include household residential investment in the overall household expenditure and thus exclude it from saving (residential investment is treated as part of the saving of the households in the NIPA accounts). By doing this, they arrive at the "Adjusted financial Saving Rate" at the bottom of figure 4. This is what most of us would think as saving, the difference between disposable income and overall expenditure (including residential investment), which is equal to the accumulation of financial assets or liabilities if it is negative. This measure shows an even more pronounced drop of the saving rate, around $16 \%$, in the three decades before the crisis, and it approached $-13.5 \%$ in 2005 .

These measures of saving refer to the household sector as a whole and do not distinguish between the bottom and the top of the income distribution. In another recent paper Cynamon and Fazzari (2015b) show the saving rate of the households of the bottom $95 \%$ of income distribution decreased significantly, while the saving rate of the top 5\% is stationary but counter-cyclical as this class of households tries to smooth its consumption. Another attempt to decompose the saving rate is Saez and Zucman (2014). In this case households are divided by wealth class. They also find a significant decrease of the saving rate of the households at the bottom $90 \%$ of wealth distribution, that becomes negative after the mid-1990s. However, they also find a decrease of the saving rate of the households at the top of the wealth distribution. Despite this decrease the lowest saving rate of the top $10 \%$ over the post-war period is much higher than the highest saving rate of the bottom $90 \%$ over the same period (not to talk about the top $1 \%$ ). ${ }^{8}$ Overall, we could say with confidence that that the three decades before the crisis were marked by a very significant decrease of the saving rate of the households at the bottom of the distribution which became negative at a point along the way. On the other hand we are agnostic about the saving rate at the top with different studies giving different results.

The divergent paths of the households at the top and the bottom of the distribution can also be seen if we examine the decomposition of the debt and debt-to-income ratio between the households at the bottom $90 \%$ and the top $10 \%$. Figure 5 shows that the household sector as a whole accumulated a

\footnotetext{
${ }^{8}$ As figure 4 reveals the calculation of the saving rate is sensitive to the definition of expenditure and disposable income. It is important to keep in mind that the definitions of Saez and Zucman (2014) but also of Cynamon and Fazzari (2015b) are different from those of Cynamon and Fazzari (2015a) in figure 4.
} 
Figure 5: Decomposition of Household Debt, 1982-2012 (Billions of USD)

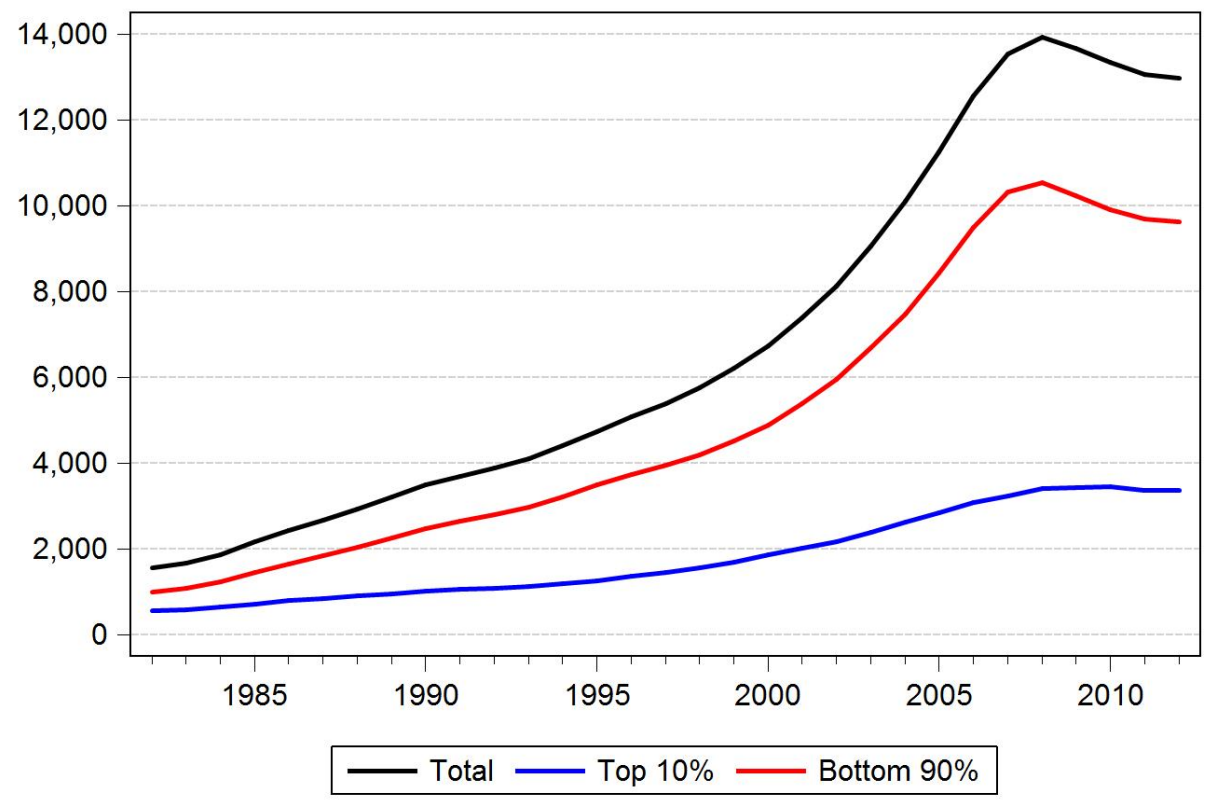

Sources: Federal Reserve, author's calculations

Figure 6: Household Debt-to-Disposable-Income Ratios, 1982-2012

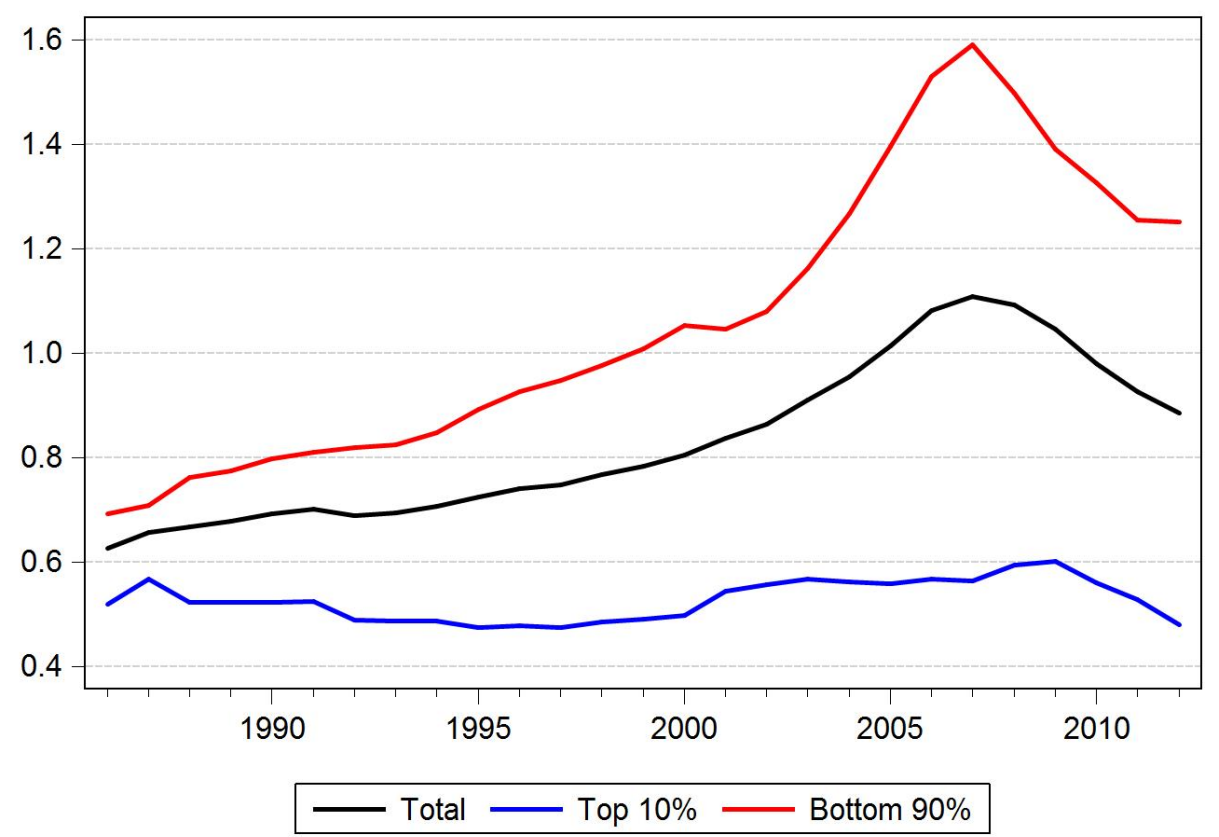

Sources: Taylor et al. (2013), Federal Reserve, Alvaredo et al. (2014), BEA, author's calculations 
vast amount of debt in the period between the early 1980s and the crisis of 2007. However, this debt was disproportionately assumed by the households at the bottom $90 \%$ of the distribution.

The pace of accumulation of debt by the household sector was so fast that it led to an increase of the debt-to-disposable-income ratio from 0.65 in the mid-1980s to more than 1.1 on the eve of the crisis (Figure 6). Again we can see that the trajectory of the debt to income ratio is very different for the households at the bottom and the top. Households at the bottom $90 \%$ saw a spectacular increase of their debt to income ratio that reached 1.6 in the eve of the crisis. On the other hand, the debt-to-income ratio of households at the top remained stationary.

Taken together, figures 3, 5, and 6 provide evidence that households at the bottom $90 \%$ of the distribution started borrowing in order to finance the increasingly large gap between their income and "normal" consumption. In a paper that provides a very detailed examination of the composition of the balance sheets of the US households - especially of the "middle class" Wolff (2012) writes:

Where did the borrowing [of the middle class] go? Some have asserted that it went to invest in stocks. However, if this were the case, then stocks as a share of total assets would have increased over this period, which it did not (...) Moreover, they did not go into other assets. In fact, the rise in housing prices almost fully explains the increase in the net worth of the middle class (...) Instead, it appears that middle class households, experiencing stagnating incomes, expanded their debt in order to finance normal consumption expenditures ( $\mathrm{p}$. 23).

Finally, in the same paper Wolff calculates the mean net worth by wealth class for the years 1983 and 2010. We present his results in Table 2. We can see that the average wealth of the wealthiest $1 \%$ rose by almost 7 million (or 71\%). The average wealth of the next 4\% increased by 1.5 million (or $101 \%$ ), while the bottom $5 \%$ of the wealthiest decile increased its average wealth by half a million (or $83 \%$ ). In total, the wealthiest decile gained $90 \%$ of the total wealth that was created at this period. This comes in sharp contrast to what happened at the middle and the bottom of the distribution. The average wealth of the third quintile decreased by $17.9 \%$. Finally, the bottom $40 \%$ experienced a $270 \%$ decrease of its average wealth over this period. In other words, not only did the wealthiest households appropriate all the wealth that was created in the period 1983-2010, but the lower-middle class and the poorest part of the population lost ground in absolute terms. 
Table 2: Mean Net Worth by Wealth Class, 1983 and 2010 (thousands 2010 dollars)

\begin{tabular}{|c|c|c|c|c|c|c|c|c|c|}
\hline & $\begin{array}{c}\text { Top } 1 \\
\text { Percent }\end{array}$ & $\begin{array}{l}\text { Next } 4 \\
\text { Percent }\end{array}$ & $\begin{array}{l}\text { Next } 5 \\
\text { Percent }\end{array}$ & $\begin{array}{l}\text { Next } 10 \\
\text { Percent }\end{array}$ & $\begin{array}{l}\text { Top } 20 \\
\text { Percent }\end{array}$ & $\begin{array}{l}\text { 4th } 20 \\
\text { Percent }\end{array}$ & $\begin{array}{l}\text { 3rd 20 } \\
\text { Percent }\end{array}$ & $\begin{array}{c}\text { Bottom } 40 \\
\text { Percent }\end{array}$ & All \\
\hline 1983 & 9,599 & 1,588 & 690 & 372 & 1,156 & 179 & 74.2 & 6.3 & 284.4 \\
\hline 2010 & 16,439 & 3,192 & 1,263 & 567 & 2,061 & 216 & 61 & -11 & 463.8 \\
\hline$\%$ change & 71.3 & 101.1 & 83 & 52.1 & 78.3 & 21.4 & -17.9 & -269.7 & 63.1 \\
\hline$\%$ of gain & 38.1 & 35.8 & 16 & 10.8 & 100.7 & 4.3 & -1.5 & -3.8 & 100 \\
\hline
\end{tabular}

More formally, we can trace the implications of changes in distribution of income for saving, debt and net worth with the help of the SAM in Table 3. The only difference with the SAM of the previous section is that the household sector is now split into households at the bottom $90 \%$ of the distribution and households at the top 10\%. In that sense, our framework departs from the conventional approach (also followed by Kaldor and Pasinetti), where the household sector is divided between workers, who receive wages and capitalists who receive profits. We thus move from a functional to size distribution approach. This approach has three advantages. First, it can take into account the distribution of the wage bill. The inequality in the distribution of the wages has been a major driver of the increase in the overall inequality of income (Carvalho and Rezai, 2015, Elsby et al., 2013). Second, within this framework, it is easier to examine the re-distributive role of the government. Finally, this setup is obviously more compatible and easier to communicate with the vast recent literature that is framed in size-distributional terms (e.g., Piketty and Saez, 2003, Alvaredo et al., 2014, Galbraith, 2012, Wolff, 2012).

It is straightforward to see — by analogy to equation (4) - that

$$
\left\{S_{90}+S_{10}+S_{c}-P I\right\}=\left\{(P G-T)+\left(Q_{g h}+Q_{g f}\right)\right\}+\left\{\left(P X-e P^{*} M\right)-\left(Q_{h f}+Q_{g f}\right)\right\}
$$

The saving of the household sector is now decomposed into the saving of the bottom $90 \%$ and the top $10 \%$. Using the same notation as above we can rewrite this as

$$
\left\{S_{90}+S_{10}+S_{c}\right\} / P Y=g v+d+c a
$$

We can then define the following distributional parameters:

i) $\alpha$ is the share of the wages of the bottom $90 \%$ in the total wage bill; $W_{90}=\alpha W$

ii) $\beta$ is the share of the profits of the bottom $90 \%$ in the total distributed profits; $\Pi_{90}=\beta\left(1-s_{c}\right) \Pi$ 


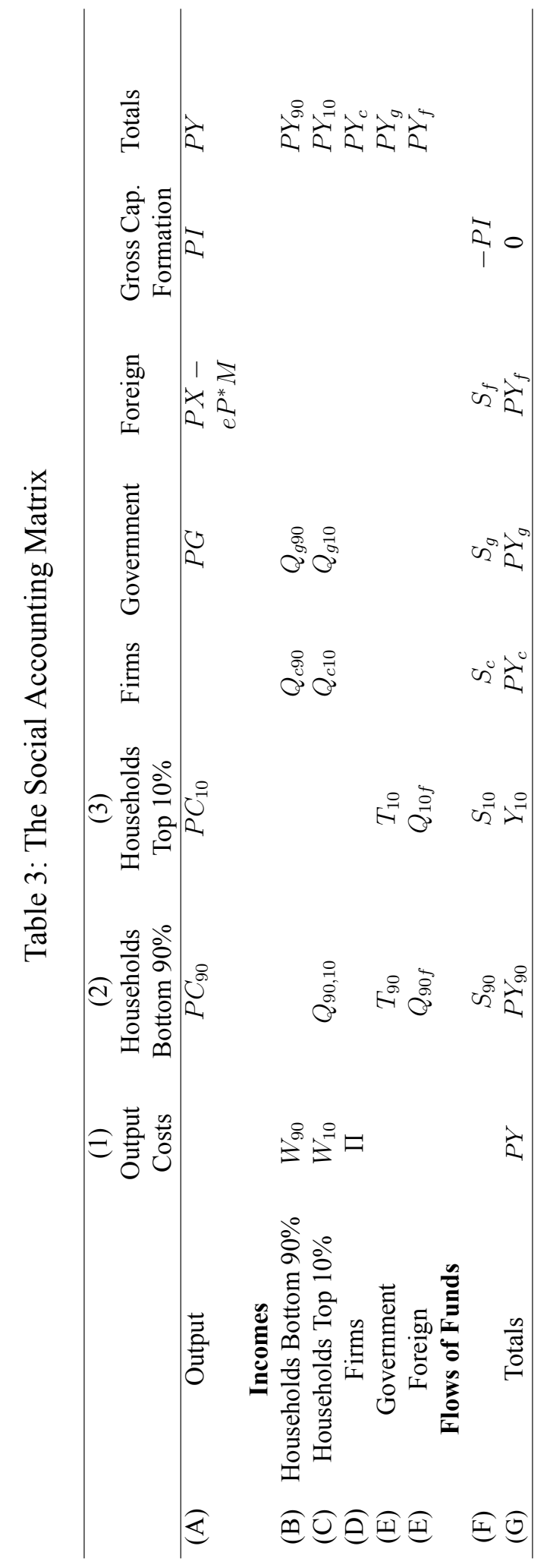


iii) $\gamma$ is the share of the government transfers going to the bottom $90 \%$ households; $Q_{g 90}=\gamma Q_{g h}$

iv) $\delta$ is the share of the total taxes paid by the bottom $90 \%$ households; $T_{90}=\delta T$

v) $h$ is the wage share; $W=h \cdot P Y$

vi) $t$ is the tax rate $T=t \cdot P Y$

vii) $q$ is the ratio of government transfers to total income; $Q_{g h}=q P Y$

viii) $\zeta$ is the ratio of transfers from the bottom $90 \%$ households towards the top $10 \%$ households to total income

Using these parameters we can rewrite the elements of the LHS of equation (11) normalized to total income as

$$
\begin{gathered}
\frac{S_{90}}{P Y}=s_{90}\left[\alpha h+\beta\left(1-s_{c}\right)(1-h)+\gamma q-\delta t-\zeta\right] \\
\frac{S_{10}}{P Y}=s_{10}\left[(1-\alpha) h+(1-\beta)\left(1-s_{c}\right)(1-h)+(1-\gamma) q-(1-\delta) t+\zeta\right] \\
\frac{S_{c}}{P Y}=s_{c}(1-h)
\end{gathered}
$$

where $s_{90}$ and $s_{10}$ are the saving rates of the households at the bottom $90 \%$ and top $10 \%$.

We can denote the share of the income of the bottom $90 \%$ of households over total income, which is the content of the square bracket of equation (12), as $\psi$, and the related share of the top $10 \%$ as $\pi$; the latter is obviously the content of the square bracket of equation (13).

Based on these definitions and with the use of equations (12), (13), and (14), we can rewrite equation (11) as

$$
s_{90} \psi+s_{10} \pi+s_{c}(1-h)=g v+d+c a
$$

How do the distributional parameters that we defined above affect the distribution of income between the bottom $90 \%$ and the top $10 \%$ ? An increase in $\alpha, \beta$, and $\gamma$-an increase in the share of wages, profits and government transfers going to the bottom $90 \%$-increases $\psi$ and decreases $\pi$. On the other hand an increase in $\delta$ and $\zeta$ - the share of total taxes paid by the bottom $90 \%$ and the income transfers from the bottom $90 \%$ to the top $10 \%$ - decreases $\psi$ and increases $\pi$. Finally, an increase in the tax rate $(t)$ decreases, while an increase in the government transfers $(q)$ increases both shares. 
The effect of a change in the wage share $(h)$ is ambiguous; $\partial \psi / \partial h=\alpha-\beta\left(1-s_{c}\right)$ and in theory can be either positive or negative. However, it is clear that the share of the wage bill going to the bottom $90 \%(\alpha)$ is much larger than the share of the profit bill going to them $(\beta)$. Therefore, the partial derivative is positive and an increase in the wage share leads increases $\psi$. In the same way we can show that $\partial \pi / \partial h<0$.

If, as before, we treat distribution, the government and current account balance and the corporate saving rate as exogenous and we further assume that the households of the top $10 \%$ can adjust their saving rates autonomously, we can come up with a non-behavioral theory of saving for the households of the bottom $90 \%$. From equation (15) the saving rate of the households of the bottom $90 \%$ that is necessary to maintain the full employment growth rate $g$ is

$$
s_{90}=\frac{(g v+d+c a)}{\psi}-s_{10} \cdot \frac{\pi}{\psi}-s_{c} \cdot \frac{(1-h)}{\psi}
$$

It is easy to see that (as before) ceteris paribus a decrease in the government deficit or the current account surplus leads to a decrease in the saving rate at the bottom of the distribution if full employment is to be maintained. The increase in the saving rate of the households at the top of the distribution or the firms has a similar effect.

To disentangle the effect of the various distributional variables that we defined above,using that $\psi+\pi=1+(q-t)-s_{c}(1-h)$ we can rewrite equation (15) as

$$
s_{90}[1+(q-t)]+\left(s_{10}-s_{90}\right) \pi+\left(1-s_{90}\right) s_{c}(1-h)=c
$$

where $c=g v+d+c a$. The differential form of equation (15') is

$$
\psi \cdot d s_{90}+\pi \cdot d s_{10}+\sum_{\kappa=\alpha, \beta, \gamma} \frac{\partial f}{\partial k} \cdot d k+\frac{\partial f}{\partial \delta} \cdot d \delta+\frac{\partial f}{\partial s_{c}} \cdot d s_{c}+\frac{\partial f}{\partial h} \cdot d h+\frac{\partial f}{\partial \zeta} \cdot d \zeta=d c
$$

where $f\left(s_{90}, s_{10}, \alpha, \beta, \gamma, \delta, s_{c}, h, \zeta\right)=s_{90}[1+(q-t)]+\left(s_{10}-s_{90}\right) \pi+\left(1-s_{90}\right) s_{c}(1-h)$. From equation (17) it is not hard to see that ceteris paribus the saving rate of the bottom $90 \%$ will decrease when:

i) The share of wages $(\alpha)$, profits $(\beta)$ and government transfers $(\gamma)$ going to the bottom $90 \%$ decrease; $d s_{90} / d k>0$ because $\frac{\partial f}{\partial k}=\left(s_{10}-s_{90}\right) \frac{\partial \pi}{\partial \boldsymbol{z}}<0$.

ii) The share of total taxes paid by the bottom $90 \%(\delta)$ increases; $d s_{90} / d \delta<0$ because $\frac{\partial f}{\partial \delta}=$ $\left(s_{10}-s_{90}\right) \frac{\partial \pi}{\partial \delta}>0$.

iii) The income transfers from the bottom $90 \%$ to the top $10 \%(\zeta)$ increase; $d s_{10} / d \zeta<0$ because 


$$
\frac{\partial f}{\partial \zeta}=\left(s_{10}-s_{90}\right) \frac{\partial \pi}{\partial \zeta}>0 .
$$

iv) The wage share decreases; $d s_{90} / d h>0$ because $\frac{\partial f}{\partial h}=\left(s_{10}-s_{90}\right) \frac{\partial \pi}{\partial h}-\left(1-s_{90}\right)<0$.

v) The saving rate of the firms increases; $d s_{90} / d s_{c}<0$ because $\frac{\partial f}{\partial s_{c}}=\left(s_{10}-s_{90}\right) \frac{\partial \pi}{\partial s_{c}}+\left(1-s_{90}\right)(1-$ h) $>0$.

It is obvious that the sign of the effects of changes in the various distributional variables depends on the plausible assumption that the saving rate of the top $10 \%$ is higher than the saving rate of the bottom $90 \%, s_{10}-s_{90}>0$. Using equation (17) we can also formally derive the effects of changes in the fiscal stance of the government, the current account, the saving of the top $10 \%$, and the corporate sector.

In summary, the maintenance of full employment requires a decrease in the saving rate of the bottom $90 \%$ in the face of an increase in income inequality (through the various channels we specified above), a decrease in the government deficit or the current account surplus, or an increase in the saving rate of the households at the top of the distribution or the firms. During the three decades before the crisis, all the aforementioned variables - probably with the exception of $s_{c}$ and $s_{10}$ - moved toward such a direction that the decrease in the saving rate of the households in the bottom $90 \%$ of distribution was necessary if full employment was to be kept over time.

Finally, by plugging equation (16) into equations (1) and (2) we can trace the trajectory of the balance sheets of the households at the bottom $90 \%$ of the distribution

$$
\begin{aligned}
& {\left[\frac{\dot{\Omega}}{P Y_{90}^{d}}\right]=\left\{\frac{(g v+d+c a-\theta)}{\psi}-s_{10} \cdot \frac{\pi}{\psi}-s_{c} \cdot \frac{(1-h)}{\psi}\right\}-\left(\pi+g_{90}\right) \frac{\Omega}{P Y_{90}^{d}}+\pi_{A} \frac{P_{A} A}{P Y_{90}^{d}}} \\
& {\left[\frac{\dot{D}}{P Y_{90}^{d}}\right]=-\left\{\frac{(g v+d+c a-\theta)}{\psi}-s_{10} \cdot \frac{\pi}{\psi}-s_{c} \cdot \frac{(1-h)}{\psi}\right\}-\left(\pi+g_{90}\right) \frac{D}{P Y_{90}^{d}}+\hat{A} \frac{P_{A} A}{P Y_{90}^{d}}}
\end{aligned}
$$

Equations (1") and (2") show the dual negative effect of increasing inequality on the balance sheets of the households at the bottom of the distribution. On the one hand, increasing inequality means stagnating real incomes for these households, a very low $g_{90}$ (see figure 3 ). On the other hand, it tends to decrease their saving rate. It thus exerts a negative pressure on both the numerator and the denominator of the debt-to-income ratio. The low saving rate also tends to decrease the net worth (although obviously in this case the low growth rate of income tends to increase the net-worth-toincome ratio). This can explain the developments in the balance sheets of the households in figures (5) and (6) and table 2.

Moreover, equations (16), (1") and (2") show that decreasing saving rate of the households at the bottom of the distribution and the related changes in their balance sheets should not be interpreted 
only in relation to the distribution of income. The developments in the current account and the fiscal stance of the government also play a role.

As before, equations (1") and (2") show the necessity of asset price inflation for the maintenance of full employment. In fact, when we take into account income inequality, the real economy is at the mercy of the stock market to a greater extent than before; an asset price bubble is even more necessary in order to hide the unsustainability of this process.

\section{DISCUSSION}

This framework allows the examination of a series of interesting issues related to the origins of the crisis, the crisis itself, and the recovery. In this section we discuss the validity of the arguments that put the blame for the crisis on the "irresponsible" behavior of the households at the bottom of the distribution, the relation between (un)sustainability and closure, and finally, the current anemic recovery and the prospect of secular stagnation.

\subsection{Morality Stories}

In the aftermath of the crisis, there were many economists, policymakers and commentators who put the blame for the crisis on the households at the bottom of the distribution. According to this view, the crisis was the result of the irresponsible behavior of the households at the bottom of the distribution, who consumed beyond their means. This - as equation (2") shows-led to the increase of their debtto-income ratio and ultimately to the Great Recession.

There are various possible objections to this kind of argument. For example, from a moral point of view, it is unfair to put all the blame on the irresponsible behavior of the borrowers, and at the same time absolve of any responsibility the lenders who facilitated or in many cases triggered the lending behavior of the households. Similarly, as we will discuss below, the lower saving rate of the households at the bottom of the distribution was, to a large extent, a response to the need to purchase some basic goods that were previously provided by the government.

All these objections aside, we can approach this issue from a purely macroeconomic point of view. As we discussed in the previous section given the increase in the current account deficit, the fiscal consolidation and the increase in income inequality, the decrease in the saving rate of the households at the bottom $90 \%$ of income distribution was a prerequisite for the growth rate to remain constant and full employment to be maintained. If we go back to equation (15'), which we rewrite below for reasons of convenience, if $d$ and $c a$ on the LHS decrease, while on the RHS income inequality $(\pi)$ (and $s_{10}$ and $s_{c}$ remain constant) the only way for $g$ to remain constant is through a decrease in $s_{90}$.

Having at the same time high external deficits, low fiscal deficits, high income inequality, high saving rate for the bottom $90 \%$ and full employment is impossible. 


$$
s_{90}[1+(q-t)]+\left(s_{10}-s_{90}\right) \pi+\left(1-s_{90}\right) s_{c}(1-h)=g v+d+c a-\theta
$$

In other words, given the high external and low fiscal deficits and the increase in income inequality, the maintenance of full employment hinges on an "irresponsible" behavior on behalf of the households at the bottom of the distribution and an unsustainable increase in their stock of debt and their debt-to-income ratio, and the bubbles that facilitated this process. Even if irresponsibility, debt, and bubbles did not exist, it would be necessary to invent them.

\section{2 (Un)Sustainability and Closure}

An unsustainable process has to end sooner or later. In terms of closure, that means that another variable or set of variables has to adjust so that the basic macroeconomic identity $S=I$ is satisfied; the closure of the system has to change. This is an important point if we want to understand the crisis and the weak economic recovery of the post-crisis period in the US and elsewhere.

As we explained above, the growth of the US economy before the crisis was based, to a large extent, on an unsustainable decrease in the saving rate of the households at the bottom of the distribution and thus to an increase in their debt-to-income ratio. The crisis ensued when this process/closure exhausted its limits. The closure of the system had to change. Figure 4 shows that the crisis was preceded by the reversal of the three decade long trend of decreasing saving rates. Based on equation $\left(15^{\prime}\right)$ it is easy to see that, given the $c a$, if the households at the bottom of income distribution choose a high saving rate, that would maintain or reduce their debt-to-income ratio and the system has to close through the endogenous adjustment of either income inequality, the fiscal deficit $(d)$, or the growth rate and unemployment $(g)$; either inequality has to decrease, or fiscal deficits increase, or the growth rate will decrease (or some combination of the three).

Thus, the crisis itself is nothing but the break in the closure. The adjustment took place through the growth and the unemployment rate. The fiscal stimulus of 2009, the so-called American Recovery and Reinvestment Act, managed to mitigate the effects by absorbing a part of the required adjustment.

We can understand the ongoing recovery in a similar way. The recovery of output and employment that started in the third quarter of 2009 has been the weakest in the post-war period. In the first quarter of 2015 , six years into the recovery, output was only $8.4 \%$ and employment only $2 \%$ higher than its pre-crisis level (Papadimitriou et al., 2015). Why is this happening? In the period after the crisis, the households of the bottom $90 \%$ have been trying to deleverage and they have increased their saving rate. At the same time, as figure 2 shows, income inequality has kept increasing. Finally, fiscal conservatism has prevailed; this is the only recovery in the post-war period where there is a decrease in real government expenditure in absolute terms. As a result, we are back to a conventional Keynesian world where the adjustment takes place through the growth rate and employment. 


\subsection{Policy Implications and the Prospect of Secular Stagnation}

This analysis has important policy implications for the future. Under its current structural characteristics, the US and other developed economies face two options. On the one hand, the current situation can continue: households at the bottom of the distribution will deleverage, current account deficits persist, the government will be fiscally conservative, and income inequality will remain high (or will further increase). Thus the system will continue to adjust through the growth rate and employment and the US economy will face a prolonged period of secular stagnation. This is a more straightforward way to approach the issue of secular stagnation than the loanable funds approach (and the zero lower bound of the nominal interest rate) that is adopted by modern proponents of the theory like Lawrence Summers (2014) and Paul Krugman (2014). ${ }^{9}$

On the other hand, there might be a repeat of the pre-crisis closure and the system achieves full employment along the lines of our theory of saving. Demand will be generated through an endogenous adjustment of the saving rate of the households at the bottom of the distribution, while all the other macroeconomic variables (fiscal and external deficits and inequality) remain constant. Some kind of asset bubble will be needed to support this process. For the reasons we outlined above, this kind of closure is inevitably unsustainable and is bound to end with yet another crisis. Summers (2014, p.66) makes a similar point: "... as the United States and other industrial economies are currently configured, simultaneous achievement of adequate growth, capacity utilization, and financial stability appears increasingly difficult."

Therefore, the only sustainable way to maintain full employment (stable debt-to-income ratios combined with a full employment growth rate) is through a change of the current configuration, a change in the structural characteristics of the economy. More precisely, with reference to equation $\left(15^{\prime}\right)$, adjustment needs to come through decrease in the inequality of the distribution of income and the current account deficits, but also with the increase in fiscal expenditure.

\section{BEHAVIORAL FOUNDATIONS}

The goal of this paper is to highlight the non-behavioral dimension of saving. We showed that in the face of income inequality, higher current account deficits and fiscal consolidation, the saving rate of the households at the bottom of the distribution has to decrease in order for full employment to be maintained. Nevertheless, it is worth saying a few words about the behavioral foundations of this kind of theory.

The question we need to answer is what makes the household sector reduce their saving to

\footnotetext{
${ }^{9} \mathrm{~A}$ summary of the recent views on secular stgantion is provided in Teulings and Baldwin (2014). The idea is much older and goes back at least to the 1930s. Significant related contributions include Steindl (1952), Baran and Sweezy (1966) and Hansen (1939).
} 
such low levels that their debt becomes unsustainable. In particular we need to explain this kind of behavior for the households at the bottom of the distribution. As we saw, the debt-to-income ratio of the households at the top remained constant and their net worth increased a lot, so there is no real mystery there. On the other hand, the behavior of the households at the bottom is more perplexing, especially if someone's starting point is the neoclassical, rational household and the life-cycle/permanent income hypothesis (Modigliani and Brumberg, 1954, Friedman, 1957).

A better starting point is Veblen's Theory of the Leisure Class (1899). In this classic book, Veblen argues that in each society, the standard of living is determined by those at the top of the distribution: "all canons of reputability and decency, and all standards of consumption, are traced back by insensible gradations to the usages and habits of thought of the highest social and pecuniary class - the wealthy leisure class" (p. 81).

Veblen makes this observation in passing; the goal of his treatise was different and much more general. A more systematic treatment of the specific issue of the saving decisions of households is provided by Duesenberry (1949). He argues that the utility of an individual is not a function of the absolute level of consumption, but rather of the level of consumption relative to the consumption of her reference group. Thus, the saving rate is an increasing function of the relative income (the income relative to the income of the reference group) and not the absolute level of income. This so-called relative income hypothesis can explain both the observed higher saving rates of the households at the top of the distribution, as well as the relative stationarity of the aggregate saving rate as income grows. ${ }^{10}$

As it is common with most economic ideas, the seeds of this relative income hypothesis can be traced back to the classical political economists. Adam Smith in a chapter entitled "Of the origin of Ambition and of the distinction of Ranks" in The Theory of Moral Sentiments (1759, p. 83) writes that "Nothing is so mortifying as to be obliged to expose our distress to the view of the public, and to feel, that though our situation is open to the eyes of all mankind, no mortal conceives for us the half of what we suffer. Nay, it is chiefly from this regard to the sentiments of mankind, that we pursue riches and avoid poverty." Nine decades later, Karl Marx in his pamphlet "Wage-Labour and Capital" (1849, p. 33) observes that "A house may be large or small; as long as the neighboring houses are likewise small, it satisfies all social requirement for a residence. But let there arise next to the little house a palace, and the little house shrinks to a hut."11

One clear corollary of this approach to saving is that as income inequality increases, the saving

\footnotetext{
${ }^{10}$ The relative income hypothesis was meant to be a critique of the standard consumer theory but also the Keynesian consumption function. The latter can explain the differential saving rate for different income classes but not the stationarity of the saving rate as income grows. It has been sidelined by the so-called life cycle hypothesis (Modigliani and Brumberg, 1954) and permanent income hypothesis (Friedman, 1957), which are now the standard neoclassical theories of consumption and income, despite their inability to explain the patterns of saving and income.

${ }^{11}$ Smith is quoted in Luttmer (2005) and Marx in Easterlin (1995).
} 
rate of the households at the bottom of the distribution will tend to decrease as they will try to "keep up with the Joneses" (an expression that is commonly in the English-speaking world to describe the same idea).

Several more recent contributions provide further justification for the propositions of Veblen and Duesenberry. Frank (1985, 1997 and Frank et al., 2014) argues in favor of the utility function as proposed by Dueseneberry and provides related empirical evidence. He makes the interesting point that this kind of utility function was shaped by the forces of natural selection. Higher income and consumption relative to someone's reference group was related to his/her reproductive success and is thus "hard-wired" in the human preference system. Thus, from an evolutionary perspective, this kind of behavior of household is completely rational, albeit in a different sense than the neoclassical definition of rationality.

Easterlin (1974, 1995, 2001) compares happiness (or subjective well-being, or welfare, or utility) studies across different societies over time. He points out that within a given society at a given point in time happiness is positively correlated with income. On the other hand, he does not find this kind of correlation across countries. He also shows that for the United States the growth of GDP and income over time is only slightly associated with increase in the happiness indices. He interprets these results as a confirmation of the relative income hypothesis.

Schor (1999) provides a discussion of what she calls new consumerism, which has led to extensive overspending of the American middle class after the 1970s (the decrease in the saving rates of the household sector and the increase of its debt-to-income ratio are the most obvious indicators of this kind of overspending). She examines this phenomenon from many different angles and points out that increasing income inequality is among the primary reasons that have created it.

Also, in relation to our argument, Christen and Morgan (2005), as well as Bertrand and Morse (2013), show that increasing income inequality has contributed to the increase in consumer borrowing. A similar argument is put forward by Rajan in his popular book Fault Lines (2010).

Alvarez-Cuadrado and Van Long (2011) propose a theoretical model that combines the permanent with the relative income hypotheses. They show that the competitive equilibrium of the model is not efficient and they propose — as Frank (1997) — a progressive consumption tax. Bowles and Park (2005) opt for the same solution. In their paper they set up a model and provide empirical evidence that show that higher income inequality is associated — through a Veblenian mechanism — with longer working hours. In a similar vein, Neumark and Postlewaite (1998) provide a theoretical and empirical justification that relative income concerns lead to the increase in the participation of the women in the labor force.

Zizzo and Oswald (2001) provide evidence from a laboratory experiment in which people are willing to pay in order to reduce (to "burn") other people's money. Charles et al. (2009) propose a model where conspicuous consumption is used as a signal for a household's income. They confirm 
their conclusion econometrically and discuss how these results are related to race. Heffetz (2011) shows that data confirm a conspicuous consumption model where the higher the visibility of a good is the higher is its income elasticity of demand. Kuhn et al. (2011) examine data from the Netherlands and show that people living next door to lottery winners "have significantly higher levels of car consumption." Guven and Sørensen (2012) stress the importance of perceptions: happiness is related to the perceived rather than the actual relative income and status. Daly et al. (2013) find a statistical linkage between relative income and suicide deaths in the United States. Finally, Maurer and Meier (2008) and Luttmer (2005) provide further empirical evidence in favor of the relative income hypothesis.

Obviously, this kind of theory of saving applies to the degree that it is sustainable or if it is unsustainable to the degree that financial markets accommodate it. As we saw in the case of the US, the saving rate of the household sector became negative and the debt-to-income ratio was increasing at an exponential rate. This was possible only because the financial system accommodated this decrease in saving and increase in indebtedness. This process is bound to change through both demand and supply of credit effects: the saving behavior and thus the demand for credit will change as household try to deleverage and the financial system will stop accommodating such a process.

Finally, the decrease in the saving rate of the households at the bottom of the distribution is also related to the retrenchment of the state from the provision of some basic goods. In the context of our model this can be captured through the variables $\gamma$ and $q$. As the state stops providing some basic goods the households have to step in and cover that expenditure. This has obvious negative effects on their saving rates. An obvious example of this kind of good is education. The increasing cost of education in the United States has led more and more students to assume vast amounts of debt. According to the most recent data from the Household Debt and Credit Report of the New York Fed, the stock of student loan debt outstanding in the last quarter of 2014 was close to 1.2 trillion dollars up from 0.25 trillions just one decade later. Someone could make a similar argument for the cost of healthcare.

\section{CONCLUSION}

In this paper, we provided a non-behavioral theory of saving: what needs to be the saving rate of the household sector if full employment is to be kept over time. Our analytical framework originates in the seminal papers by Nicholas Kaldor (1955)and Luigi Pasinetti (1962). However, we apply a different closure. In our model, distribution of income is determined exogenously. Thus, for a constant growth rate to be maintained, there has to be an endogenous adjustment of the saving rates.

At a first stage, unlike Kaldor and Pasinetti, we do not distinguish between different types of households. However, our economy has a government and a foreign sector. In this case we show that the saving rate of the household sector becomes a function of the fiscal and current account deficits. In the face of an increase in the current account deficit and fiscal surplus, the maintenance of full 
employment becomes dependent on a decrease in the saving rate of the private sector. However, such a decrease tends to increase the debt-to-income ratio and decrease the net-worth-to-income ratio of the household sector, and is therefore unsustainable. This is the basic idea of Wynne Godley's Seven Unsustainable Processes (1999).

At a second stage we split the household sector into those households at the bottom $90 \%$ of the distribution and those at the top $10 \%$. We show that in addition to the external and fiscal position of the economy, an increase in the saving rate of the households at the bottom of the distribution becomes a function of distribution of income as well. An increase in income inequality requires a decrease in the saving rate of the households at the bottom of the distribution ceteris paribus.

Based on this analysis, it is not hard to identify the roots of the Great Recession. In the period before the crisis, the increasing income inequality and deterioration of the external position of the US economy, coupled with a pervasive fiscal conservatism made full employment dependent on the decrease of the saving rate of the households, especially those at the bottom of the distribution. This process led to a spectacular increase in their debt-to-income ratio, and could be sustained only as long as an asset (stock market or real estate) bubble was there to support it. When the drop in the saving rate stopped and the bubble burst, the Great Recession naturally followed.

Through this prism, the "irresponsible" behavior of the households at the bottom of the distribution and the drop in their saving rate was necessary for the healthy growth rate that the US economy enjoyed in the three decades before the crisis. Given the increase in inequality and the current account deficit and the culture of of fiscal conservatism that pervaded the US politics, the economy faced a dilemma between full employment based on the aforementioned unsustainable process or low growth rates and high unemployment.

The same basic dilemma applies in the present and for the future. Under the present circumstances the US has to choose between yet another round of unsustainable private expenditure or a prolonged period of low growth - a secular stagnation. The only escape from this dilemma can come through a relaxation of fiscal stance of the government and most importantly through addressing the main structural problems of the economy, high income inequality and external deficits. 


\section{REFERENCES}

Alvaredo, F., A. B. Atkinson, T. Piketty, and E. Saez (2014). The World Top Incomes Database,. date accessed: 2 April 2014.

Alvarez-Cuadrado, F. and N. Van Long (2011). The relative income hypothesis. Journal of Economic Dynamics and Control 35(9), 1489-1501.

Baran, P. and P. Sweezy (1966). Monopoly Capital. New York, NY: Monthly Review Press.

Bertrand, M. and A. Morse (2013). Trickle-down consumption. Technical report, National Bureau of Economic Research. Working paper 18883.

Bowles, S. and Y. Park (2005). Emulation, Inequality, and Work Hours: Was Thorsten Veblen Right? The Economic Journal 115(507), F397-F412.

Carvalho, L. and A. Rezai (2015). Personal income inequality and aggregate demand. Cambridge Journal of Economics.

Charles, K. K., E. Hurst, and N. Roussanov (2009). Conspicuous consumption and race. Quarterly Journal of Economics 124(2), 425-467.

Christen, M. and R. M. Morgan (2005). Keeping up with the Joneses: Analyzing the effect of income inequality on consumer borrowing. Quantitative Marketing and Economics 3(2), 145-173.

Cynamon, B. Z. and S. M. Fazzari (2015a). Household Income, Demand, and Saving: Deriving Macro Data with Micro Data Concepts. Review of Income and Wealth. fortcoming: doi: 10.1111/roiw.12206.

Cynamon, B. Z. and S. M. Fazzari (2015b). Inequality, the Great Recession, and Slow Recovery. Cambridge Journal of Economics. forthcoming, doi: 10.1093/cje/bev016.

Daly, M. C., D. J. Wilson, and N. J. Johnson (2013). Relative status and well-being: evidence from US suicide deaths. Review of Economics and Statistics 95(5), 1480-1500.

Duesenberry, J. (1949). Income, Saving, and the Theory of Consumer Behavior. Harvard Economic Studies. Cambridge, MA: Harvard University Press.

Easterlin, R. A. (1974). Does economic growth improve the human lot? Some empirical evidence. In P. David and M. W. Reder (Eds.), Nations and households in economic growth, pp. 89-125. New York and London: Academic Press.

Easterlin, R. A. (1995). Will raising the incomes of all increase the happiness of all? Journal of Economic Behavior \& Organization 27(1), 35-47.

Easterlin, R. A. (2001). Income and Happiness: Towards a Unified Theory. The Economic Journal 111(473), 465-484.

Elsby, M. W., B. Hobijn, and A. Şahin (2013). The decline of the US labor share. Brookings Papers on Economic Activity 2013(2), 1-63.

Foley, D. K. and T. Michl (1999). Growth and Distribution. Cambridge, MA: Harvard University 
Press.

Frank, R. H. (1985). The Demand for Unobservable and Other Nonpositional Goods. The American Economic Review 75(1), 101-116.

Frank, R. H. (1997). The frame of reference as a public good. The Economic Journal 107(445), $1832-1847$.

Frank, R. H., A. S. Levine, and O. Dijk (2014). Expenditure Cascades. Review of Behavioral Economics 1(1-2), 55-73.

Friedman, M. (1957). A Theory of the Consumption Function. Princeton, NJ: Princeton University Press.

Galbraith, J. (2012). Inequality and Instability: A Study of the World Economy Just Before the Great Crisis. Oxford University Press, USA.

Godley, W. (1999). Seven unsustainable processes: medium-term prospects and policies for the United States and the World. Technical report, Levy Economics Institute.

Guven, C. and B. E. Sørensen (2012). Subjective well-being: Keeping up with the perception of the Joneses. Social Indicators Research 109(3), 439-469.

Hansen, A. H. (1939). Economic Progress and Declining Population Growth. The American Economic Review 29(1), 1-15.

Heffetz, O. (2011). A test of conspicuous consumption: Visibility and income elasticities. Review of Economics and Statistics 93(4), 1101-1117.

Kaldor, N. (1955). Alternative Theories of Distribution. The Review of Economic Studies 23(2), 83-100.

Kaldor, N. (1957). A Model of Economic Growth. The Economic Journal 67(268), 591-624.

Krugman, P. (2014). Four observations on secular stagnation. In C. Teulings and R. Baldwin (Eds.), Secular Stagnation: Facts, Causes and Cures. London, UK: CEPR Press. A VoxEU.org eBook.

Kuhn, P., P. Kooreman, A. Soetevent, and A. Kapteyn (2011). The Effects of Lottery Prizes on Winners and Their Neighbors: Evidence from the Dutch Postcode Lottery. The American Economic Review 101(5), 2226-2247.

Luttmer, E. F. P. (2005). Neighbors as Negatives: Relative Earnings and Well-Being. The Quarterly Journal of Economics 120(3), 963-1002.

Marglin, S. A. (1984). Growth, distribution, and prices. Cambridge, MA: Harvard University Press. Marx, K. (1933 [1849]). Wage-Labour and Capital, Volume XXXVII of Marxist Library, Works of Marxism-Leninism. New York, NY: International Publishers.

Mason, J. W. and A. Jayadev (2014). "Fisher Dynamics" in US Household Debt, 1929-2011. American Economic Journal: Macroeconomics 6(3), 214-34.

Maurer, J. and A. Meier (2008). Smooth it Like the 'Joneses'? Estimating Peer-Group Effects in 
Intertemporal Consumption Choice. The Economic Journal 118(527), 454-476.

Minsky, H. (1975). John Maynard Keynes. New York: Columbia University Press.

Minsky, H. (1986). Stabilizing an Unstable Economy. New Haven, CT: Yale University Press.

Modigliani, F. and R. Brumberg (1954). Utility analysis and the consumption function: an interpretation of cross-section data. In K. Kurihara (Ed.), PostKeynesian Economics. New Brunmswick, NJ: Rutgers University Press.

Neumark, D. and A. Postlewaite (1998). Relative income concerns and the rise in married women's employment. Journal of public Economics 70(1), 157-183.

Palma, J. G. (2009). The revenge of the market on the rentiers.: Why neo-liberal reports of the end of history turned out to be premature. Cambridge Journal of Economics 33(4), 829-869.

Papadimitriou, D. B., G. Hannsgen, M. Nikiforos, and G. Zezza (2015, May). Fiscal Austerity, Dollar Appreciation, and Maldistribution Will Derail the US Economy. Strategic Analysis, Levy Economics Institute.

Pasinetti, L. L. (1962). Rate of Profit and Income Distribution in Relation to the Rate of Economic Growth. The Review of Economic Studies 29(4), 267-279.

Piketty, T. and E. Saez (2003). Income inequality in the United States, 1913-1998. The Quarterly Journal of Economics 118(1), 1-41.

Rajan, R. G. (2010). Fault Lines: How Hidden Fractures Still Threaten the World Economy. Princeton, NJ: Princeton University Press.

Ryoo, S. (2015). Inequality of Income and Wealth in the Long Run: a Kaldorian Perspective. University of Massachusetts Amherst, Department of Economics Working Papers Series 2015-09.

Saez, E. and G. Zucman (2014, October). Wealth Inequality in the United States since 1913: Evidence from Capitalized Income Tax Data. Working Paper 20625, National Bureau of Economic Research.

Schor, J. (1999). The Overspent American: Why We Want What We Don't Need. Current affairs. HarperCollins.

Sen, A. (1963). Neo-Classical and Neo-Keynesian Theories of Distribution. Economic Record 39(85), 53-64.

Smith, A. (2002 [1759]). The Theory of Moral Sentiments. Cambridge Texts in the History of Philosophy. Cambridge, UK: Cambridge University Press.

Steindl, J. (1952). Maturity and Stagnation in American Capitalism. Oxford: Basil Blackwell.

Summers, L. H. (2014). U.S. Economic Prospects: Secular Stagnation, Hysteresis, and the Zero Lower Bound. Business Economics 49(2), 65-73.

Taylor, L. (2004). Reconstructing Macroeconomics: Structuralist Proposals and Critiques of the Mainstream. Cambridge, MA: Harvard University Press.

Taylor, L. and F. J. Lysy (1979). Vanishing income redistributions: Keynesian clues about model 
surprises in the short run. Journal of Development Economics 6(1), 11-29.

Taylor, L., A. Rezai, R. Kumar, L. de Carvalho, and N. Barbosa (2013). US Size Distribution and the Macroeconomy, 1986-2009. Technical report, Schwartz Center for Economic Policy Analysis (SCEPA), The New School.

Teulings, C. and R. Baldwin (Eds.) (2014). Secular Stagnation: Facts, Causes, and Cures. London, UK: CEPR Press. A VoxEU.org eBook.

Veblen, T. (1973 [1899]). The Theory of the Leisure Class. Boston, MA: Houghton Mifflin Company. with an introduction by J.K. Galbraith.

Wolff, E. N. (2012). The Asset Price Meltdown and the Wealth of the Middle Class. NBER Working Paper No. 18559.

Zizzo, D. J. and A. J. Oswald (2001). Are People Willing to Pay to Reduce Others' Incomes? Annales d'Économie et de Statistique (63/64), 39-65. 